\title{
"We Are Looking for a Picasso to Strengthen Our Team ...": \\ A Manual for Creative Staff Employment
}

\author{
Magdalena Łużniak-Piecha \\ SWPS University of Social Sciences and Humanities \\ Monika Stawiarska-Lietzau \\ Jan Długosz University in Częstochowa
}

\begin{abstract}
The purpose of this paper is to present an analysis of selected organisational and individual factors affecting innovativeness of organisations. The authors have focused on the mechanisms which are triggered within an organisation whose managing officers deliberately choose to support their employees' inventiveness, creativity and provide them with talent management in order to develop a good organisational culture. This article is supposed to depict the analysed phenomena from a broad perspective. Therefore, the authors have included references not only to studies focusing on benefits which can be attained by organisations which support creativity, but also to those which analyse factors preventing companies from benefitting from an openness to innovation and creativity in their work environments.
\end{abstract}

Keywords: creativity, innovation, organisational culture, prejudices against creative people

\section{Introduction}

Creativity is an ability to develop solutions, ideas, theories, works of art, concepts or objects which are both innovative and useful (cf. Amabile, 1997, Sternberg, Lubart, 1996; Strelau, 2015). Although this notion seems to be mainly linked to fine arts and science, it may also apply to virtually any domain of human activity, such as education, career and daily life. It seems that these days creativity 
is highly appreciated in business. According to IBM report investigating the factors which affect development of companies in a complex and changeable market environment, based on opinions gathered from over 1500 CEOs representing 60 countries and 33 international companies, creativity of employees is regarded as important as that of their superiors (IBM, 2010). As one of current market standards is the demand for creative, independent, innovative, unconventional and talented employees which is often reiterated in job adverts, the title of the present article has been deliberately exaggerated to reflect this phenomenon. But what does really happen if such an employee starts acting in an innovative, independent and nonstandard way? Are contemporary companies ready to hire a 'Picasso'? Can managers effectively cope with the changing organisational cultures, management strategies and roles in companies hiring creative and unconventionally working people? Is there the right understanding of the much-desired employee creativity? What attributes do creative individuals have? Does hiring creative people guarantee a company any specific profits?

The purpose of the present analysis is to investigate the benefits which can be attained by inviting creative individuals to corporate environments. However, in this context, the notion of 'creative individuals' will not be limited to artists only. In fact, this paper will be focusing on the mechanisms triggered within an organisation whose managers have decided to rely on invention, creativity and talent management when developing their organisational cultures, also when it comes to choosing employees. Such organisations often hire creativity coaches, artists and consultants to support creative thinking, innovation and creativity. Such corporate development formula appears to be both attractive and politically correct. The authors concentrate upon certain phenomena which can be observed within organisations when creative individuals promote their standpoints and philosophies, thus reshaping well-established mechanisms of their cultures. In some cases, this results in clashing of old corporate routines with new and innovative ones. In order to broaden up this analysis, the authors have referred to the studies covering three different, yet closely correlated concepts such as: creative attitude, creativity and innovation. Creative attitude consists in assuming of a nonstandard but, at the same time, constructive approach to solving problems (Amabile, 1988). Meanwhile, creativity is an ability to generate ideas and solutions which are regarded both as innovative and useful both by creators and their surroundings, as well as by other committed or interested parties (Csikszentmihalyi, 1999). Innovation, in turn, involves putting into practice any creative ideas that have been generated within organisations by those showing creative attitudes (Amabile, 1988).

The present paper aims at analysing selected organisational and individual factors affecting innovativeness of an organisation. We have analysed the benefits 
which can be attained by organisations opening themselves to creative thinkers, employees and groups. What is important in this context is a broad perspective of our investigation. In fact, the authors make reference not only to studies devoted to benefits of creativity within organisations, but also to those examining the factors preventing companies from benefiting from opening their labour environments to innovation and creativity.

\section{Innovative development, i.e. corporate profits generated by creativity}

When invention and creativity have started to be regarded as crucial for organisations, they have also become a popular topic of trainings, development programmes and HR strategies. Organisations have started to establish special departments in charge of talent management, which has also become a subject of scientific research and academic programmes. Individuals in charge of fostering creative skills within organisations, researchers and practitioners exploring practical applications of arts and creative activities in the contemporary business environment and supportive organisational cultures strongly believe that such areas are highly important, or even crucial for contemporary businesses. From the psychological point of view, this reasoning is quite legitimate, as commitment to objectives which we ourselves consider topical is a natural and primal human need (Frankl, 1959). In fact, few of us would deliberately sacrifice our careers or private lives to anything that we personally consider irrelevant. However, there is always a risk for the one to get profoundly immersed into the subject by getting surrounded by the experts who share the same viewpoint (as all of us would rather co-operate with intelligent people who cherish the same opinions, passions and understanding of important issues...) and lose the broader outlook. Even professionals, organisational and strategic management experts who have supported creative thinking of their employers for many years in order to follow their venturesome strategies can fall victim to the false assumption of "being globally understood by others" (Hergovich, Schott, Burger, 2010). Yet, Forgeard and Kaufman (2016) have posed an interesting and provocative question in their study: "Who cares about imagination, creativity and innovative thinking and what do we need them for?" This question seems to be particularly valid for big companies where 'time is money' and 'life is driven by procedures'.

Obviously, the one who asks: "Who cares about creative thinking in the age of rush and crisis management?" may be considered as 'ignorant' and 'lacking understanding for the cause'. Yet, this question may also be perceived as an important issue worth tackling both from scientific and practical points of view. 
Creativity coaches, talent managers and artists cooperating with companies often wonder how mutual impacts of arts and business should be leveraged to make work environments more friendly, 'pro-human' and, at the same time, creative and innovative. Meanwhile, specific reasons why creativity and innovation are so important at workplaces should be pinpointed and named. Can we generate any short or long-term benefits by deploying art and creativity? If so, what kind of benefits? Will these benefits offer a good return on investment that we have made by 'inviting' art into our offices and conference rooms both in terms of our financial costs, personal commitment and time? Will talent managers, creativity coaches and all those who co-operate with the world of art and artists pass the 'Who cares?' test successfully at the organisational level? (Forgeard, Kaufman, 2016).

When answering all these questions we should go back to the definition of creativity quoted in the introduction. If creativity is to be understood as an ability to generate ideas or solutions which are regarded as innovative and useful by their authors, their surroundings, as well as by other committed or interested individuals (Csikszentmihalyi, 1999), then such ideas can be regarded as foundations of technological and organisational development. Being ahead of our competitors, both in terms and technology and organisational structure, is a determinant of our competitive edge. Offering employees an opportunity to experiment with art at their workplaces and encouraging them to create art by themselves in a climate which fosters innovative fulfilment of their job-related tasks favourably affects their mental wellbeing and increases their commitment to solving problems or disputes (Forgeard, Elstein, 2014). Łużniak-Piecha and Stawiarska-Lietzau (2015a, 2015b) point out to an importance of promoting independence, innovative thinking and supportive workplace atmosphere for the development of employers' branding and prevention of organisational pathologies (cf. Stawiarska-Lietzau, Łużniak-Piecha, 2014).

Forgeard and Kaufman (2016) in their thought-provoking research referred to in the above paragraph tried to answer the following question: "Who cares about creativity at workplaces and what do we need them for?" and came up with a list of reasons why businesses decided to exploit creativity, innovation and creative thinking.

The first of these reasons is a better job satisfaction and corresponding improvement of the quality and efficiency of the work. Apart from 'faster and better-quality work', this also leads to strengthening bonds between employees who support one another and improve their performance. Thanks to such mutual support, the level of work-related stress is reduced, employees became capable of motivating one another and engaging into fruitful discussions in search for better 
solutions. Members of an organisation trust one another and the level of other job-related satisfaction increases (Forgeard, Kaufman, 2016). Such organisational culture is also more effective when it comes to preventing pathologies. There is no place for 'toxic' or pathological behaviours in a team whose members trust one another, think in a nonstandard way and willingly cooperate with one another (Stawiarska-Lietzau, Łużniak-Piecha, 2014).

The second reason, which is somewhat related to the first one, has to do with employees' health and wellbeing (Forgeard, Kaufman, 2016). An employee's physical and mental wellbeing benefits from being in a supportive environment when they can overcome stress, creatively resolve disputes and develop an organisational culture which favours innovation. Such environments also allow one to effectively deal with strategies that are detrimental to an organisational culture such as for e.g. treating others rudely (Stawiarska-Lietzau, Łużniak-Piecha, 2014, 2017a, 2017b).

The third group of reasons also corresponds to the issues referred to above and includes improvement of the quality of communication and teamwork, as well as social or interpersonal skills of individuals within an organisation (Forgeard, Kaufman, 2016). Creative co-operation also requires openness to brand new, nonstandard and striking ideas and solutions proposed by workmates. It also entails coming up with unconventional, yet beneficial, solutions to problems reported by the organisation's customers. All these factors contribute to promoting a positive image of an organisation in its business environment among its members, customers or partners (Łużniak-Piecha, Stawiarska-Lietzau, 2015b).

Another factor making creativity beneficial for an organisation is strengthening its competitive, business, commercial and productive advantage (Forgeard, Kaufman, 2016). Creativity is an essential element of a flexible development, effective organisational changes and ability to adapt to the rapidly changing markets and consumer preferences.

Yet another reason is providing employees with an opportunity for personal fulfilment and success (Forgeard, Kaufman, 2016). Many strategies aimed at attracting and retaining top professionals and most talented experts which have been developed over the years are based on improving personal satisfaction and pride of being part of an organisation and acting as an independent project creator, rather than on purely economic incentives. Although the ones regarded as crème de la crème also expect to be reimbursed nicely, they are likely to abandon an organisation which does give their skills and talents enough room to flourish.

Some reasons seem to stem from social, historical and political advancements. Tackling of organisational diversities and providing equal opportunities to members of various ethnic, racial and gender groups, people with disabilities and 
representatives of different generations are the issues that require state-of-the art solutions. By taking advantage of such solutions, organisations get an opportunity to develop and proliferate their social and cultural, and implicitly, also financial capitals (Forgeard, Kaufman, 2016; Łużniak-Piecha, Lenton, 2016).

In the light of the above arguments presented by Forgeard and Kaufman, workplace benefits of creativity are quite substantial. This assumption is confirmed by the opinions of managers and strategies aimed at discovering employees' creativity. It needs to be determined, however, whether such demand for creative individuals is dictated by genuine and profound interest in their unique skills or rather stems from the fact that creativity is 'trendy'. The authors' perceptions of different work environments and their research and consulting experience prove that in many organisations, including those concerned with ongoing development (e.g. R\&D entities), the understanding of creativity and its management are inadequate. We can then legitimately ask though-provoking questions such as: "What do we need creative employees for? And how are we going to use them?".

\section{Creative employees, i.e. personal aspects of creativity}

Our analysis of the most effective uses of employees' creativity should start with taking a better look at creative individuals. Some researchers argue whether creativity characterises exceptional and outstanding people only (i.e. "We are looking for a Picasso") or rather is present, to a varying extent, in all of us (cf. Nęcka, 2001; Strelau, 2015). Barsalou and Prinz (1997) proposed to resolve this dispute by differentiating between a 'down-to-earth' vs. 'exceptional' creativity. The 'exceptional' creativity includes creating works of art, making discoveries and inventions that affect entire communities. Meanwhile, the 'down-to-earth' one is an ability to come up with new solutions at individual level. The researchers claim that even though the down-to-earth creativity is not so spectacular as the exceptional one, it is still equally important for our adaptive skills: "[...] the down-to-earth creativity is a true workhouse pulling the majority of achievements of the mankind and making the exceptional one possible at all" (Barsalou, Prinz, 1997; after: Nęcka, 2001, 21). In the contemporary creativity studies such point of view seems to be quite prevalent. Creativity is perceived as a constant feature which is displayed by people in varying degrees, starting from minimum to maximum one in the case of the greatest creators. Apparently, big companies do not really look for talents such as the one shown by the famous cubist painter, but they do hope to find people who would meet their complex and nonstandard expectations. 
If this is the case, we might ask ourselves how one can 'hunt for' creative individuals in the recruitment process. According to individual differences psychology, there exists a collective set of traits, which are typical of creative people including cognitive, personal and motivational features. The cognitive features ${ }^{1}$ include, e.g. divergent thinking i.e. processing of information which leads to coming up with many alternative solutions, as well as plasticity, fluency and uniqueness of thinking combined with a relatively high IQ (even though people with high IQs are not always creative) or a specific cognitive style including, among others, reflexivity and field-independence (cf. Amabile, 1997, Nęcka, 2001, Strelau, 2015). Creativity highly depends on knowledge about a given field (cf. Nęcka, 2001, Strelau, 2015, Sternberg, Lubart, 1991).

Such personality traits as openness, independence and persistence (Nęcka, 2001, cf. Strelau, 2015) also play an important role. Openness is an ability to assimilate new information, regardless of whether such information is valid, reliable or consistent with the possessed knowledge, a tendency to take interest in highly diversified topics such as for e.g. the ones going far beyond one's professional domain and fondness of novelties involving the need for stimulation, unusual sensations and tolerance of ambiguity and vagueness (Nęcka, 2001, pp. 132-133). Independence of creative individuals is often manifested by their nonconforming behaviour i.e. resilience to social influences, and preference of their own objectives over standards or goals imposed by others, and tendency to question and reject authority figures combined with nonconventional beliefs and readiness to defend their own standpoints (Nęcka, 2001, pp. 134-135). Meanwhile, persistence is demonstrated by their readiness to work hard for a long period of time without a quick reward expectation, combined with the willingness to cope with challenges without getting frustrated easily (Nęcka, 2001, pp. 137-138).

Teresa Amabile, a researcher who has been investigating creativity for many years, and an author of the Componential Theory of Creativity, claims that creativity can be divided into the following three components (Amabile, 1997):

- specialist knowledge and skills on which creativity is based present a unique cognitive map allowing to locate a problem within a specific context and analyse it from different points of view;

1 A detailed description of cognitive aspects of creativity goes beyond the scope of the present papers. For more information on this topic please see: T.B. Ward, S.M. Smith, J. Vaid (1997), Creative thought: An investigation of conceptual structures and processes. Washington, DC: American psychological Association; Nęcka, E. (2001). Psychologia twórczości. Gdańsk: Gdańskie Wydawnictwo Psychologiczne. 
- creative skills including for e.g. openness to new ideas, persistency at work, self-discipline, readiness to take risks, tolerance for ambiguity and disregard for social approval;

- intrinsic motivation understood as a readiness to take up challenges just for the sake of satisfaction manifested by genuine interest and commitment, curiosity, pleasure and perception of specific tasks as personal challenges.

Pursuant to this theory, individuals will be most likely to undertake creative actions if their knowledge and creative skills are reinforced by a strong intrinsic motivation to act. Moreover, the level of creativity will also depend on the intensity of the aforementioned creativity components (Amabile, 1997). The author also believes that an intrinsic motivation to act is a trigger for employees' creativity.

Apparently, there is a group of employees who have a profound knowledge of a given field and a strong intrinsic motivation to act, acquire new skills and develop their competencies. Sounds like a description of a perfect worker? On the other hand, however, we should keep in mind that such people do not care much for external approval, and have their own independent opinions supported by expert knowledge and prefer to follow their own beliefs or values. They also regard creative disputes as valuable and are eager to experiment with new or nonstandard solutions. In other words, they are not likely to fit well into all work environments, especially the ones which, as Forgeard and Kaufman (2016) stated, do not allow their personal skills and talents to 'flourish'.

\section{The creative climate, i.e. organisational determinants of creativity}

Based on the above description of creative individuals we can conclude that creativity stems from certain personal aptitudes which make those who possess them an attractive asset for an organisation, provided, however, that such organisation creates adequate conditions enabling the use of innovation in an effective and reasonable way. How can an organisational culture allowing for the effective use of employees' creativity be established? Sadly, in some companies 'opening up to innovation' ends up at the stage of a recruitment campaign. Will selection of the right staff guarantee that an organisation will be perceived as innovative on the labour market? "If you want to gain a competitive edge, you need to hire creative employees" - this is a philosophy practiced by many managers and CEOs which finds its reflection for e.g. in employment adverts indicating creativity as one of the most wanted features of successful candidates. Unfortunately, hiring creative people will not help much if no supporting actions at an organisational level are taken. 
Professor Amabile and her team have been studying creativity in work environments for many years. Their studies have demonstrated an importance of interactions between employees' creativity and work environment. Amabile also believes that each averagely talented individual can, at least from time to time, perform moderately creative tasks in a specific field and his or her work environment impacts both quality and frequency of such creative performance (Amabile, 1997, Amabile et al., 1996). Whether an employee will actually think and act creatively, does not depend on his or her aptitude only, but also, and perhaps most of all, on the actual understanding and support by the managing staff at all levels of an organisation.

Based on interviews with members of project teams in which their working conditions and creativity at work were examined, Amabile and her team defined a group of factors on which a creative climate at work depended. These factors included: supportive organisation and superiors, supportive team members, availability of necessary resources, providing employees with challenges and autonomy (Amabile, 1997; Amabile et al., 1996; Amabile, Sensabaugh, 1992).

The organisational support is manifested by a culture that encourages creativity among employees (Amabile et al., 1996, pp. 1156-1161):

- encouragement to take risk and present unique ideas and positive attitude towards innovation represented by managers at all levels. Some psychological studies have already proven that people are more likely to come up with nonstandard and useful ideas if they are encouraged to do so in a specific situation, or explicitly instructed to so in writing.

- unbiased and constructive assessment of new ideas - a probability that such assessment will be critical and threatening, increases employees' anxiety and has an adverse impact on their creativity. On the other hand, a conviction that the superior's assessment is going to be reliable and supportive gives an employee more sense of freedom and improves his or her intrinsic motivation to act (cf. Deci \& Ryan, 1985). In other words, employees' creativity will be used most effectively in an environment where "one free to experiment and make mistakes". Meanwhile, in such environments where one must always act by the rules and "is not allowed to make mistakes" creative employees will also take use their skills but mainly in order to "cover up their mistakes" and "create untrue reports"...

- rewarding and appreciating creativity - even though studies have demonstrated that commitment to work that is mainly motivated by a prospective reward decreases one's intrinsic motivation and also creativity, the appreciation of an employee's creativity or proposal of a reward, not as the ultimate goal, but an extra bonus, or promising him or her a better or more interesting work in 
the future, definitely reinforces such person's eagerness to come up with new solutions and increases their number and frequency (cf. Nęcka, 2001).

- flow of common ideas across an organisation and opportunity to take part in management and decision-making processes - creative ideas are more likely to proliferate when employees have an opportunity to watch their workmates coming up with creative solutions that are useful for an organisation.

The working climate fostering creativity also requires support on the part of superiors and project teams. The superiors are the key persons that affect employees' behaviours and shape the emotional ambience at work (cf. Stawiarska-Lietzau, Łużniak Piecha, 2017a; Stawiarska-Lietzau, Łużniak-Piecha, 2017b). Managerial support can be manifested, most of all, by a clear definition of work objectives, support and trust, appreciation for each employee's contribution as well as by open and constructive assessment of their ideas (Amabile et al., 1996). What also helps to release an employee's creativity is a team support which manifests itself in several different ways such as e.g. team composition. Creativity can be triggered by the diversity of team members in terms of their specialisation, work seniority, professional experience, nationality, gender, etc. Such diversity gives the team members an opportunity to view problems from different perspectives, and facilitates mental processes aimed at generating creative solutions (cf. Payne, 1990). Other factors that affect creative processes substantially include: unrestricted communication between team members, openness to ideas proposed by others, sense of challenge (i.e. being part of a major and unique project) and collective engagement. As it has already been mentioned, diversification of teams and opportunity to watch unrestricted generation of ideas one's workmates contributes to a 'creative climate' which inspires and encourages specific individuals, while the sense of challenge and commitment reinforce their intrinsic motivation to act which is one of the key factors supporting creative processes (Amabile et al., 1996; Nęcka, 2001).

An important aspect of the support of employees' creativity in an organisation is the proper planning of their work, including the availability of necessary resources such as cash, materials, facilities and data, and providing individuals with freedom to act. The sense of autonomy is inherently connected to a creative process which requires freedom and the possibility of unrestricted and nonstandard processing of information and generation of alternative solutions. By creating adequate working conditions and offering employees freedom to act we make them think that they are part of a major project that is worth investing into, and that we perceive them as competent and reliable, which, in turn, strengthens their intrinsic motivation to act (Payne, 1990; Amabile et al., 1996). 
Ekvall and Ryhammar have proposed a similar definition of the components of creative working climate (Ekvall, Ryhammar, 1999; after: Nęcka, 2001, p. 151). In such climate:

- employees perceive the tasks that are assigned to them as a challenge and important part of an organisation's development;

- employees have freedom to act and express their ideas;

- new ideas are welcomed and supported by their superiors and workmates;

- employees are not afraid of being criticised or ridiculed by others when presenting their ideas;

- an exchange of new ideas among members of an organisation is not governed by rigid rules and can take include everyone regardless of their roles within the workplace hierarchy;

- taking moderate risks is permitted without pressure on short-term results or necessity to demonstrate the rationale of one's ideas.

Implicitly, a creative climate in an organisation entails openness to nonstandard ideas of employees and readiness to support such ideas, even if some of them may fail, and provide employees with considerable autonomy.

\section{Creative anxiety, i.e. difficulties which must be overcome at an organisational level}

The considerations presented above prove that the co-operation with creative individuals, such as artists or consultants representing other disciplines, may turn out to be very beneficial. But on the other hand, such cooperation may not be handled well by managers who are not accustomed to trusting their subordinates and giving them freedom to act and who are not willing to abandon their meticulous control procedures (cf. Łużniak-Piecha, Stawiarska-Lietzau, 2015b; Stawiarska-Lietzau, Łużniak-Piecha 2017a). Miron, Erez and Naveh demonstrated (2004) that creative employees are likely to be perceived as less concerned with details, 'tidy desktops' and workplace discipline, and may refuse to 'follow orders unthinkingly'. Therefore, in such a case, such managers must confront a challenge including, on the one hand, the need of fostering innovation and independence in creative problem handling, and on the other hand, confronting their own lack of confidence in management of a team composed of creative experts who sometimes may be unwilling to follow orders. Mueller, Goncalo and Kamdar (2011) have indicated that people working in business environments often develop covert biases towards creative individuals who are perceived as 'problematic workers', as they often refuse to comply with well-established rules governing corporate 
cultures, ask nonstandard questions and want to know not only 'what' needs to be done, but 'why' and propose alternative solutions. Moreover, such employees are also perceived as individuals favouring their personal development over the organisation's interest. They also tend to engage into disputes which they consider 'creative discussions' but can be perceived by some managers as a plain deviation from the 'no discussion' rule. Li and Kaufman (2014) have pointed out to a similar paradox by describing simultaneous desire for creative individuals and their rejection. In their studies they have demonstrated that despite the fact that creativity is considered as one of the most important attributes that employees may have, many companies prefer not to employ creative individuals because they are perceived as daredevils and nonconformists, and such behaviours are generally not welcomed in organisations. A similar phenomenon can be observed at schools where teachers claim that they value creativity among students but, on the other hand, they dislike personality traits that typical of creative individuals who are perceived as disturbing, arrogant and wayward.

"Hire good people and leave them alone" was a motto coined by William McKnight, the CEO of an US based company named 3M in the 1930s and 40s. (Gustaw, 2015). This philosophy also contributed to the market success of one of the most innovative companies of the $20^{\text {th }}$ century. Apparently, an ability to lead a team composed of innovative experts who are not concerned with social approval but follow their own systems of values and express unpopular opinions is a unique skill of transformation leaders who are well-fitted for their roles and capable of ensuring innovative motivation and management (Eużniak-Piecha, Stawiarska-Lietzau, 2015b). Meanwhile, the so-called transactional leaders (i.e. the ones less willing to loosen their control), an ideal employee should be creative only at prescribed times and when performing specific tasks i.e. 'on demand' and when asked to. Unfortunately, as we have demonstrated at the end of our paper, demanding such obedience from employees, exerting pressures upon them and subjecting them to meticulous control often kill creativity in a team.

Obviously, we are not claiming that as a result of making a business enterprise open to the co-operation with artists, hiring creative individuals and fostering innovative problem-solving methods, employees would suddenly become wayward, deadlines would not be observed and budgetary constraints would be ignored. The purpose of the above considerations was to answer the question whether exposing businesses to arts, creativity and innovative problem-solving methods would generate specific benefits. The foregoing analysis also indicates a number of conditions which must be met by individuals shaping organisational cultures and managers in order to ensure that an exposure of an organisation to arts and creative approach to handling work-related tasks would provide it with 
measurable benefits. In this context we would like to highlight the importance of an organisational culture fostering innovation and avoid mindless repetition of such slogans as: "We would like to become an innovative enterprise", "Management in our organisation is a creative process", "We have decorated our premises with contemporary works of art in order to foster a creative working climate".

Since such attributes as creativity, innovation and ability to co-operate with creative individuals are valued by societies (Forgeard, Kaufman, 2016), but at the same time, difficult to be standardised and vague, many individuals think of themselves as creative and openminded. In many environments, open-mindedness is regarded as a much-welcomed attribute. However being brave and ready to open oneself to something that is new, different, unknown e.g. shocking beliefs of other people, is not always easy and, definitely, does not come up automatically. One of the authors of the present article once received an invitation for a certain creative event. The hosts of the event were known as creative individuals who support creativity. At the same time, however, in their invitations they provided a very detailed agenda divided into specific topics which were supposed to be covered by specific invitees in their papers ... Luckily for all, such co-operation was not governed by the 'no room for discussion' rule! The above situation presents yet another example of the dilemmas which can be faced by managers who are in charge of budgets and timely supplies but, at the same time, would like to promote organisational cultures based on innovation and creativity.

\section{Conclusion}

On 3 September 1948 Pablo Picasso visited a modern residential quarter which had been recently reconstructed in Warsaw Koło District. The artist was fascinated by the 'cubist views' that he discovered in this area. To express his excitement, he spontaneously sketched a huge bare-breasted Mermaid holding a hammer in her hand on a new apartment's wall. Soon afterwards a family moved in. The place soon became a famous destination which attracted groups of visitors who arrived there just to admire the work of the famous artist. Even though this phenomenon initially appealed to the Mermaid's new cohabitants, making them feel proud, it soon turned into a huge inconvenience. Eventually they asked their housing managers for a permission for renovation works. The head of the housing cooperative issued such permission and workers soon appeared at the site. They just glanced at the Mermaid and one of them said: "Just tell me who has scribbled this thing. My brother-in-law is a better painter". Then he splashed out the paint ... and the Mermaid by Picasso disappeared from Koło District forever... 
The above analysis has been meant to demonstrate that the key factor determining the effective use of employees' creativity in an organisation is understanding of its essence and capability of an equally creative use of such potential for the benefit of the organisation. Otherwise, 'innovation and creativity' will only remain cheap slogans reminding of the propaganda which used to be disseminated by the comrades who invited Picasso to a modern residential quarter.

\section{References}

Amabile, T.M. (1988). A model of creativity and innovation in organizations. Research in Organizational Behavior, 10, 123-167.

Amabile, T.M. (1993). Motivational synergy: Toward new conceptualizations of intrinsic and extrinsic motivation in the workplace. Human Resource Management Review, 3.

Amabile, T.M. (1997). Motivating Creativity in Organizations: On Doing What You Love and Loving What You Do. California Management Review, 40(I), 39-58.

Amabile, T.M., Conti, R., Coon, H., Lazenby, J., Herron, M. (1996). Assessing the work environment for creativity. Academy of Management Journal, 39(5), 1154-1184.

Csikszentmihalyi, M. (1999). Implications of a systems perspective for the study of creativity. In: R.J. Sternberg (Ed.), Handbook of creativity. New York, NY: Cambridge University Press, 313-335.

Deci, E.L., Ryan, R.M. (1985). Intrinsic motivation and self-determination in human behavior. New York: Plenum.

Ekvall, G., Ryhammar, L. (1999). The creative climate: Its determinants and effects at a Swedish university. Creativity Research Journal, 12, 303-310.

Forgeard, M.J.C., Elstein, J.G. (2014). Advancing the clinical science of creativity. Frontiers in Psychology, 5, 613.

Forgeard, M.J.C., Kaufman, J.C. (2016, August). Who cares about imagination, creativity, and innovation, and why? Psychology of Aesthetics, Creativity, and the Arts, 10(3), 250-269.

Frankl, V. (1959). Man's search for meaning: An introduction to logotherapy. Boston, MA: Beacon Press Books.

Gustaw, G. (2015). Premia szacunkowa. Polityka Poradnik Psychologiczny, 17, 54-59.

Hergovich, A., Schott, R., Burger, C. (2010). Biased evaluation of abstracts depending on topic and conclusion: Further evidence of a confirmation bias within scientific psychology. Current Psychology, 29, 188-209.

IBM 2010 Global CEO Study: Creativity Selected as Most Crucial Factor for Future Success. Retrieved from: https://www-03.ibm.com/press/us/en/pressrelease/31670.wss (accessed: 12.11.2017). 
Li, Q., Kaufman, J. (2014). Creativity: Definitions and conceptualizations. In: J.A. Plucker, C.M. Callahan, (Eds.), Critical issues and practices in gifted education: What the research says. Waco, TX, US: Prufrock Press, 173-182.

Łużniak-Piecha, M., Lenton A. (2016). Supporting Employee Health and Well-being as a Strategy for Managing an Age-diverse Workforce. Greater London Authority Case Study. Zeszyty Naukowe Uczelni Vistula, 46(1), 142-160.

Łużniak-Piecha, M., Stawiarska-Lietzau, M. (2015a). Relacje społeczne w patologicznych kulturach organizacyjnych i ich konsekwencje na przykładzie kultury psychopatycznej i dramatycznej - zastosowanie „Koła” Shalita do analizy przypadków. Studia Społeczne, Wyższa Szkoła Menedżerska w Warszawie, 12(1), 63-74.

Łużniak-Piecha, M., Stawiarska-Lietzau, M. (2015b). Styl zarządzania a skuteczność strategii employer branding. Menedżerowie transformacyjni, transakcyjni i patologiczni. Zeszyty Naukowe Uczelni Vistula, 44(6), 145-164.

Miron, E., Erez, M., Naveh, E. (2004). Do personal characteristics and cultural values that promote innovation, quality, and efficiency compete or complement each other? Journal of Organizational Behavior, 25, 175-199.

Mueller, J.S., Goncalo, J.A., Kamdar, D. (2011). Recognizing creative leadership: Can creative idea expression negatively relate to perceptions of leadership potential? Journal of Experimental Social Psychology, 47, 494-498.

Nęcka, E. (2001). Psychologia twórczości. Gdańsk: Gdańskie Wydawnictwo Psychologiczne.

Stawiarska-Lietzau, M., Łużniak-Piecha, M. (2014). Psychopatia, narcyzm, histrionika - menedżerowie o osobowościach patologicznych i kreowane przez nich kultury organizacyjne. Wprowadzenie do badań. Edukacja Ekonomistów i Menedżerów, 4(34), 11-27.

Stawiarska-Lietzau, M., Łużniak-Piecha, M. (2017a). Krzyczeć czy nie krzyczeć styl komunikacji menedżerskiej a efektywność pracy. Edukacja Ekonomistów i Menedżerów, 2(44), 53-68.

Stawiarska-Lietzau, M., Łużniak-Piecha, M. (2017b). Zarządzanie przez lęk: patologiczni menedżerowie i emocjonalny klimat lęku jako czynniki zagrażające bezpieczeństwu psychologicznemu w miejscu pracy. Ready to be printed.

Sternberg, R.J., Lubart, T.I. (1991). An investment theory of creativity and its development. Human Development, 34, 1-31.

Sternberg, R.J., Lubart, T.I. (1996). Investing in creativity. American Psychologist, 51, 677-688.

Strelau, J. (2015). Różnice indywidualne. Warszawa: Wydawnictwo Naukowe SCHOLAR. 


\section{Magdalena Łużniak-Piecha}

A PhD in Psychology, Assistant Professor at SWPS University and Polish University Abroad in London, co-operating with Tecnologico de Monterrey in Mexico. Ms Łużniak-Piecha investigates organisational pathologies and leadership skills and introduces gamification techniques into the process of creation of organisational cultures.

\section{Monika Stawiarska-Lietzau}

A PhD in Psychology, graduate of the Jagiellonian University and Assistant Professor at Jan Długosz University in Częstochowa. Ms Stawiarska-Lietzau's academic interests are focused on risky behaviours and decisions and their underlying mechanisms, taking into consideration individual and environmental differences, as well as on psychological aspects of organisational behaviours, leadership and pathologies. She also operates her own counselling practice. 